\title{
Colonial Officials and Scholars
}

The Institutionalization of the Mon Paradigm

THE PREVIOUS eleven chapters have shown how, for over one hundred years now, the Mon Paradigm has dominated virtually all interpretations regarding the early history of Burma and also influenced aspects of early Mainland Southeast Asian studies. The question that we might be asking by now is how and when was the Paradigm institutionalized? Who was involved, and why did these particular individuals at that particular time decide to interpret Burma's history in that particular way? The question of "how," "when," and "who" can be answered relatively satisfactorily even though not as precisely as desired. But the question of "why" must necessarily be a matter of interpretation. Certainly, all involved had their own prejudices, some clearly personal. But for most, a prevailing political, academic, social, and intellectual climate seemed to have shaped their perspectives.

At the same time we must remember that these individuals were pioneers: no one before them had seriously attempted to reconstruct Burma's history in a "scientific" way. And although the indigenous chroniclers were absolutely vital for the reconstruction of a coherent narrative with specific events and individuals-without whom no history of Burma could have been written in English-and often succeeded in reconstructing certain components that we might call "scientific history," the early colonial officials and scholars who wrote about Burma were in many ways the first to do so. This is particularly true of those who wrote during the nineteenth century, without the kinds of data, tools, or information that those who wrote at the turn of the twentieth century had. Thus although my critique may sound harsh at times, and is, admittedly, done in hindsight, it is not without an appreciation of the context in which these pioneers worked. The intent here is neither to rationalize nor condemn their scholarship, but to explain in greater detail how it was responsible for the genesis, development, and perpetuation of the Mon Paradigm.

This chapter will focus on the way the Mon Paradigm became institutionalized as a school of thought in the twentieth century, but built on the 
intellectual (and ideological) foundations laid in the nineteenth. As such, the chapter really has more to do with colonial historiography than with that of early Burma. Nonetheless, its colonial underpinnings are also an important component; indeed, some might say the only important component. Although I would not go that far, it is certainly true that the way the west has understood-and in many cases, misunderstood-precolonial Burma's history, has shaped our "knowledge" of Burma today.

\section{The Origins and Development of the Mon Paradigm}

The Mon Paradigm, as we have seen, was not created by any single individual. It began with King Dhammazedi attempting to legitimate his reign and programs, continued with U Kala for reasons still not entirely clear, and only sometime in the middle of the nineteenth century were both narratives combined by colonial officials and scholars to produce the thesis that the Lower Burma Mon were responsible for the culture and civilization of the Upper Burma Burmans. This colonial combination of the two indigenous parts and their establishment as "truth" is the subject of this chapter. It first describes the political, military, academic, and personal circumstances that resurrected Dhammazedi's "legend that was Lower Burma," and then addresses the institutionalization of the thesis that the Lower Burma Mon civilized the Upper Burma Burmans.

As demonstrated in Chapter Eleven, the seeds for resurrecting Dhammazedi's linking of Suvaṇṇabhūmi and Rāmaññadesa seemed to have been sown during the First Anglo-Burmese War of 1824-1826, when the British Government of India, desiring to establish a countervailing force against the Burmese monarchy and to legitimate their conquest of Lower Burma, proposed the Pegu Project. As colonial officials were also its scholars, this resulted in scholarly attempts to establish the antiquity of a Mon kingdom in Lower Burma. If only it could be shown that Suvannạhūmi was Rāmañnadesa, or was at least located in the Lower Burma region, it would provide a most important piece of evidence to justify the reestablishment of that ancient Mon kingdom. Although Dhammazedi had made that link in the fifteenth century, no one at this time knew about it, as the Kalyani Inscriptions had not yet been rediscovered.

But historical circumstances eventually overtook the Pegu Project. The British had won both the First and Second Anglo-Burmese Wars, which landlocked the Burmese monarchy in Upper Burma. It was only a matter of time before all of Burma was finally annexed (in 1885-1886), so that the Pegu Project was really no longer needed after the Second Anglo-Burmese War of 1852, and therefore never actually implemented. However, its con- 
cerns were already part of scholarly "discourse" by then, so that the search for an ancient Mon Kingdom in Lower Burma nonetheless continued unabated, and became an integral part of English-language scholarship on the early history of Burma.

Sometime before 1860 Bishop Paul Bigandet published the first edition of The Life or Legend of Gaudama. But only with the second edition, published in 1866, was the link made between Suvaṇnabhūmi and Rāmaññadesa. ${ }^{1}$ A Capt. H. Hopkinson, commissioner of the Martaban and Tenasserim Provinces, had convinced the American Mission Press, publishers of Bigandet's second edition, to include a supplementary section "on the names and situations of the principal towns and countries, mentioned in the Legend, with the view of identifying them with modern sites and places." ${ }^{2}$ One of these was Suvaṇnabhūmi, which appears in Bigandet's second edition as the "district of Thaton ... in the country of Ramagnia. ..."3 Thus, and perhaps for the first time in the English-language scholarship of Burma, Suvạ̣nabhūmi was linked to Lower Burma via Rāmaññadesa. ${ }^{4}$

Arthur Phayre's article "On the History of Pegu" followed in 1873, where he made the same case, although in a more academic and scholarly manner. ${ }^{5}$ He cited "as his chief authority" a narrative written in "the Talaing, or Mun, language by Tsha-ya-daw A-thwa, a Buddhist monk." ${ }^{6}$ However, my research shows that this is the same work known as the Slapat Rajawain Datow Smin Ron, discussed in earlier chapters. It was not an original composition written by the monk Phayre named, but a "collation, composition, and restoration" of another historical work. ${ }^{7}$ Most important, it has nothing to say about Rāmaññadesa being Suvaṇnabhūmi, at least not in the version Halliday translated. That explains Phayre's statement that he had obtained that particular information from another source: ${ }^{8}$ namely, from "traditions current among the people of Pegu. . .."9 In other words, the belief that Rāmañnadesa was Suvạ̣nabhūmi has no better verification than "traditions current" at Pegu even by one of the foremost early colonial scholars of Burma. Perhaps for the above reasons, Phayre readily admitted that "the materials for a full history of the Mun people either do not exist, or are not now available in Pegu." 10 As we shall see, he was right on both counts, and such a full history would have to wait until 1910.

A Capt. C. J. F. S. Forbes, deputy commissioner of British Burma and Phayre's immediately subordinate, subsequently made the same connection between Suvaṇnabhūmi and Rāmaññadesa in his Legendary History of Burma and Arakan, published posthumously in 1882. ${ }^{11}$ Forbes had criticized Phayre's 1873 work on Pegu as "incomplete," while claiming that his own work had used "original Talaing” manuscripts along with U Kala's Mahayazawingyi, implying that Phayre had not. ${ }^{12}$ It is a puzzling statement, and dif- 
ficult to reconcile with what we know of Phayre's sources, which, more likely than not, Forbes had probably used freely with Phayre's knowledge and permission. ${ }^{13}$

In any case, the following year Phayre's History of Burma was published, in which he reiterated his 1873 position that "the identity of the Khryse of Ptolemy, of the Suvarna Bhumi of the Buddhist legends, and the city of Thahtun in Pegu ... appears to be certain." But this time, he cited Bigandet's second edition, which now included Captain Hopkinson's supplement regarding Suvaṇnabhūmi being Rāmaññadesa. ${ }^{14}$ Thus, the "evidence" to support that most important connection being made between Suvaṇnabhūmi and Rāmaññadesa in colonial sources was not only late, but the direct result of Captain Hopkinson's intervention that probably stemmed from the earlier concerns raised by the Pegu Project's attempts to justify the establishment of an ancient Mon kingdom in Lower Burma. Scholarship indeed followed the flag.

With regard to the second component of the Mon Paradigm-the "conquest of Thatôn"-Phayre's History was also one of the earliest publications in English to mention it, along with Forbes's Legendary History cited above..$^{15}$ But because Phayre admitted that in the "Talaing Chronicles, the conquest ... is not to be found,..."16 both he and Forbes must have obtained the story from U Kala's Mahayazawingyi, which Phayre reportedly had in his possession, and to which Forbes obviously had access as Phyare's immediate subordinate. ${ }^{17}$ Only much later, in 1910 and 1912, were the Pak Lat Chronicles published, in which the complete version of the conquest as described in U Kala first appears in the Mon language, over two decades after Phayre's and Forbes' publications in the English language had also included the event.

Yet Michael Symes nearly eighty years earlier had already mentioned that event, along with the heart of the Mon Paradigm-the civilizing of Upper Burma by the Lower Burma Mon. Symes wrote in his Journal of his second trip to Ava in 1802 that "Much of Burmese civilization, including Hinnayāna Buddhism, had come to them from the Mons, whose independent kingdom with its capital at Thaton had been conquered by King Anawrahta in the middle of the eleventh century A.D. and incorporated in the empire of Pagan." 18 Until then, no English-language source that I know of had linked the conquest with its putative civilizing consequences.

It is curious that Phayre had nothing to say about that alleged civilizing process, ${ }^{19}$ and this leads me to believe that he did not know of Symes's account, or it may not have been available at the time. The latter seems plausible, since we find no mention of this idea in the other early firsthand accounts that shortly followed Symes's, such as Hiram Cox's or John Crawfurd's. ${ }^{20}$ Nor does it appear in 1833, when Father Vicentius Sangermano 
published The Burmese Empire A Hundred Years Ago. In fact, he had nothing to say even about Aniruddha. ${ }^{21}$ It was also not part of Henry Yule's account of his mission to the court of Ava in 1855 (with Phayre), even though there was ample opportunity for the subject to come up, particularly as the two visited Pagán and made many drawings and notes about its temples. ${ }^{22}$ Perhaps they were also not privy to Symes's second journal, which was not published until much later.

By 1860, however, the Rev. Francis Mason had expressed a similar idea, writing that "Anoratha is said to have built a series of pagodas and temples, in Pugan, on the model of those then existing in Thatung [Thaton]. . ." 23 Although that idea may not have come from Symes-since he had nothing to say about Pagán temple styles being borrowed from Lower BurmaMason's sentence sounds as if he had obtained the information from someone else ("Anoratha is said to have built . . ."). Finally, after twenty more years of simmering, a most explicit statement regarding this issue was made rather forcefully, by none other than Emil Forchhammer. He wrote that "there was no Burmese civilization to speak of till the Talaings conquered the upper country [sic]," 24 "nor did they [Burmans] prior to this event [the conquest of Thatôn] possess an alphabet, much less a literature," so that "the Burmans [must have] borrowed their alphabet from the Talaings." 25

This claim, that Lower Burma Mon culture civilized Upper Burma Burman culture, the heart of the Mon Paradigm, originally made by Symes in 1802 nearly a hundred years earlier, had become, by the last quarter of the nineteenth century, the most dominating framework of analysis in the reconstruction of early Burma, which continued throughout the twentieth century in the work of seminal Burma scholars until today. ${ }^{26}$

In 1883 Forchhammer published a treatise on the ancient geography of Burma. There he attempted to link many of the toponyms in Buddhist Pali literature with those in Burma, as Bigandet's second edition had done, for by then Forchhammer was also convinced that Suvannabhūmi and Rāmaññadesa were indeed references to Mon Lower Burma. He even went so far as to state that "no reasonable objections can be raised in connecting the foundation of the Shwe Dagon Pagoda with Taphussa and Bhallika . . . in the 5th or 6th century before Christ as an accredited fact in the early history of British Burma." ${ }^{27}$ And when Phayre's history appeared in the same year, it had the effect of confirming the antiquity of Rāmañnadesa, even though Phayre had said nothing about the Mon civilizing the Burman.

It must have been shortly after Phayre's History of Burma was published that the Kalyani Inscriptions were discovered. ${ }^{28}$ Their narrative about Sona and Uttara, the Third Buddhist Council of Aśoka, and the arrival of orthodox Theravāda Buddhism in Southeast Asia clinched the issue for colonial scholarship and its view that the Suvạ̣nabhūmi of Aśokan India was indeed 
Lower Burma's Rāmaññadesa. By then the conquest of Thatôn as described in U Kala's Mahayazawingyi (if not also Michael Symes's second journal) was already familiar to colonial scholars, and thus the three critical components of the Mon Paradigm had finally come together in colonial scholarship.

Then in the winter of 1886-1887 Forchhammer discovered the Myazedi Inscriptions. Often called the Rosetta Stone of Burma, these were absolutely crucial to the confirmation and expansion of the Mon Paradigm, particularly with regard to the writing system of Burma, as we have seen. ${ }^{29}$ In the context of the recently consolidated concept that Suvạ̣nabhūmi was Rāmaññadesa, Forchhammer's assertion regarding Lower Burma's role in the civilizing of Upper Burma combined with his "downtrodden Talaing" notion to become the guiding framework of analysis for nearly every work on early Burma thereafter.

By 1909 Mabel Bode, in her Pali Literature of Burma, a seminal work in the understanding of the history of Theravāda Buddhism in Pagán and early Burma, not only continued the conquest story and its alleged civilizing consequences, but she took it for granted. She wrote: "The origin and history of the Mon or Talaing people, who were to be (unwillingly as it happened) the messengers of the purer Buddhism, need not be discussed here. The point from which we start is their acceptance of Buddhist teaching from India and the rise of a body of learned monks in Rāmañna who preserved the ancient Doctrine and Discipline and conveyed them to Upper Burma, where both had long been forgotten." ${ }^{30}$ In other words, by the time her book appeared, the Mon Paradigm had already become the point of departure rather than a thesis under discussion. But because archaeological and epigraphic discoveries showed that Pali Buddhism already existed among the Pyū well before the alleged conquest of Thatôn, Bode had to quality her perspective on the Mon Paradigm. Whereas her predecessors regarded the Mon civilizing of Upper Burma as a novel event, she saw it as a resurrection of a long-forgotten tradition.

Then came the most revealing of colonial-era texts about the Mon, the two Pak Lat volumes written in the Mon language and published in 1910 and 1912. For the first time, a "comprehensive" history of the Burma Mon had been published in their own vernacular. Not only did the complete account of Aniruddha's conquest of Thatôn appear for the very first time in the Mon language, but so did the theme made popular by Forchhammer of its consequences-the Mon civilizing of Pagán. Heretofore, although the Nidāna may have mentioned the conquest story, the supposed consequences had hitherto not been found in any other dated Mon-language source concerning Burma. It is only in the Pak Lat Chronicles that we find, for the first time in Mon, the statement that as a result of Mon culture hav- 
ing been transported to Pagán, that kingdom thereafter "flourished like unto a heavenly city." 31

This supports the contention that the Mons' realization of their plight as victims is also a late one, and was shaped, if not directly determined by turn-of-the-century colonial scholarship. Part of the reason the notion took so long to reach Mon sources is that this scholarship was published first in English, and only later was introduced to the Mon in both Burma and Siam. The Mon had had no way of knowing what was being written about them until colonial-period scholars finally told them.

Foremost among the disseminators of this information were scholars of the Mon language and culture who were in direct contact with Mon people. Especially important were the American missionary Robert Halliday, sometimes known as the "father of Mon studies in Burma"; Colonel Gerini, who knew the important Mon texts discussed in previous chapters, especially the "Gavampati," and who had published treatises on Mon proverbs in the first issue of the Siam Society's journal; Professor Schmidt of Vienna, who wrote "A History of Pegu in the Mon Language" in German; and Dr. Frankfurter, chief librarian at the National Library in Bangkok, who, with his Mon assistant Phra Tepalok, pressed for the publication of the Pak Lat volumes. ${ }^{32}$ In fact, the printer and publisher of these volumes, the superior of the Krun Cin Monastery in Thailand, at first had other priorities and had already begun publication of the Tipitakas in the Mon script. But after producing only twenty-one out of the thirty-nine anticipated volumes, he was persuaded by Frankfurter, who "urged the printing of . . . the historical books ... [as] more likely to interest the outside world; and, as a result, ... [ the two volumes] . . a appeared." ${ }^{33}$ Not coincidentally, they emerged at the beginning of the nationalistic period in Burma, when similar works were being produced by other regional ethnic groups. The Dhanyawaddy Yazawinthit" ("New history of Dhanyawaddy"), for example, which celebrated the kingdom considered by the Arakanese to have been their first, was also published in 1910 .

It is also significant that the Pak Lat volumes were published not by the Burmanized Mon of Burma but by the Mon of Siam. These were the exiled descendants of those who had fled from the seventeenth-century wars between the two countries, the eighteenth-century reunification of Burma by Alaungpaya, and the First Anglo-Burmese War. The Mon in Siam were said to have retained much of their language, culture, and identity at their community at Pak Lak, south of Bangkok. ${ }^{35}$ In contrast, the Mon who continued to live in Burma had become fairly well integrated into Burmese society. By the early twentieth century they had lost, or were rapidly losing, much of their language, culture, and identity. ${ }^{36}$ This helps explain why 
even by 1913 the Burma Mon considered neither Thatôn nor its conquest by Aniruddha to have been the national disaster that the Siamese Mon thought it had been. ${ }^{37}$

\section{Institutionalizing the Mon Paradigm}

Early one evening in 1908 or 1909, when U Tun Nyein, then government translator, was taking a walk with J. S. Furnivall, he showed Furnivall an article published by a "Burman" in the new Siam Society Journal. On his way home, Furnivall reflected that "what we need in Burma is a Burma Society," 38 and thus was born the idea of The Burma Research Society. Later he discussed his idea with Charles Duroiselle and U May Oung, and by 1910 the dream had become reality. ${ }^{39}$

The Society produced the first English-language academic journal in the country, the Journal of the Burma Research Society. It was devoted to scholarship focused on Burma, particularly its history, language, literature, ethnology, art, religion, archaeology, but on occasion, included subjects dealing with neighboring countries as well. Not surprisingly, of the first nineteen presidents (until 1959), thirteen were British colonial officials, one was an Indian, and five were Burmese. All the non-British presidents had been trained in England, or elsewhere in the English system, where they received higher degrees. Thus they were very much part of the westernized, elite class and shared, at least initially and in part, what the late Edward Said called a "consolidated vision."

Included in the very first issue of the JBRS was one article, "Some Anthropometric Data of the Talaings," which I have singled out as illustrative of the general sentiments at that time regarding ethnicity, a topic that underlay the premises of the Mon Paradigm. It was by a B. Houghton, who had measured the physical attributes of what he considered "the Talaing or Mon race." He wrote that "care was taken to avoid so far as possible any persons of Burmese or Indian blood-the Chaungzon township contains some of the purest strains of the old Talaing stock-but apart from this consideration, no attempt was made to discriminate in favour of specially good specimens, the men being measured just as they came." 40

Much of the debate in that first decade regarding Mon history assumed its antiquity and pre-Pagán existence in Lower Burma. The main actors at the time were Blagden, Cooper, Furnivall, Duroiselle, Taw Sein Ko, and May Oung. Halliday became more prominent in the second decade, and finally Luce from the 1930s onward. From its start until 1977, with a brief hiatus just prior to World War II when the journal stopped publishing temporarily, virtually all the articles dealing with the Mon in Burma either accepted or advocated the Mon Paradigm. ${ }^{41}$ Three of the last fourteen articles, in 
1976 and 1977, were written by Luce, ${ }^{42}$ who was still expounding the Mon Paradigm, and in the first volume of the last issue, Nai Pan Hla did much the same thing. ${ }^{43}$ From the first to the last issue of the JBRS, then, the Mon Paradigm reigned supreme on subjects dealing with the Mon in early Burma.

However, there was, at the beginning of the twentieth century, at least one detractor. Taw Sein Ko was an official of the Archaeological Survey of Burma, and although very much part of the "consolidated vision" of the Mon Paradigm and its generation, he nevertheless had doubts that Burma's civilization owed everything to the Mon even though he accepted the conquest story as historical and the reasons Forchhammer had proposed for the alleged oppression of the Talaings. ${ }^{44}$ But the social, academic, and administrative dominance of those advocating the Paradigm effectively isolated Taw Sein Ko's objections to a few short notes in the Journal. He eventually countered with his Burmese Sketches, two good-sized volumes published in 1913 and $1920 .{ }^{45}$ Yet to no avail, for not only did Taw Sein Ko share many of its axioms, but the Mon Paradigm had grown much larger than any single individual.

In terms of Burma's archaeology, the numerous publications produced by the Archaeological Department of India, Burma Circle, were its main outlet of information. The most prominent were the Archaeological Survey of India (and later, of Burma), Indian Antiquary, and Epigraphia Indica, along with a whole series of Annual Reports and Memoirs under the Archaeological Department of India. Some of the same people from the Burma Research Society-particularly Forchhammer, Duroiselle, and Taw Sein Ko -were also responsible for submitting the Burma sections for these journals, as well as often being involved in the actual excavations and repair of monuments in Burma.

The Archaeological Department of Burma became independent between 1901 and 1902 and thereafter published the Archaeological Survey of Burma as a separate entity. Originally in English, by the late 1940s, however, it was produced only (or mainly) in Burmese. In terms of the Mon Paradigm, virtually everything excavated or discovered in Lower Burma and reported in this journal was assumed to have been Mon. But as most of these finds were Brahmanic or Hindu rather than Buddhist, their impact on the thesis is not clear. Indeed, the information in the Archaeological Survey ultimately helped kill the Mon Paradigm, for it contained much of the data on the Pyū civilization which would eventually contradict the favored thesis. That, however, would have to wait over a hundred years.

What the parent journal, the Archaeological Survey of Burma, could not do at the time, its offspring certainly did. That offspring was Epigraphia Birmanica, probably the most important journal to institutionalize the Mon 
Paradigm, for it was virtually devoted from its inception to advancing the idea. In 1919 the first issue appeared under the directorship of Duroiselle, assistant archaeological superintendent for epigraphy. Both the conquest of Thatôn and its alleged consequences on Pagán were very much its focus. Although Forchhammer had popularized the theme earlier, Duroiselle presented an explicit articulation of the Mon Paradigm:

The result of the conquest of Thatôn was momentous for Pagan; Anorata took Manuhā, the king of Thatôn, a captive to this capital, and with him, the most learned monks, the Pali scriptures and their commentaries, and all the best artisans and artists he could find. .. . Materially the conquerors, the Burmese became, to a great extent, intellectually the conquered; . . . The form of Mahāyānism then extant at Pagán gave way to the Hīnāyanism of Thatôn; magnificent temples were built under the supervision of Indian and Talaing architects; it is only soon after 1057 that inscriptions on stone and votive tablets in Burmese, Talaing, and Pali make their appearance at Pagán. ${ }^{46}$

With these words Duroiselle not only secured the antiquity of Mon civilization in Burma as historical, but provided a believable event in Burma's early history responsible for effecting the transportation of that culture. And it was backed by a "scientific" approach in a journal modeled after the respected Epigraphia Indica. The very fact that these statements appeared in the inaugural issues of the most prestigious scholarly publication in English that dealt with primary data on early Burma meant that what had been only a theory was now an established "truth."

Thereafter, virtually every piece of archaeological, epigraphic, art historical, numismatic, and other textual evidence discovered in Lower Burma was considered to be Mon and earlier, while virtually everything found at Pagán was Burman and later. Nondescript Brahmanic, Hindu, and Buddhist artifacts, even coins without any dates or Mon writing on them, were automatically considered to have been Mon so long as they were discovered in a location considered to have been a putative Mon center, such as Pegu, and were said to have belonged to "that" pre-Pagán Mon civilization, tautologically reconfirming the theory. Presumed antiquity was now linked to artifact, ethnicity, and geography in a static and irrevocable manner. Premise and proof had become synonymous.

In the very next issue of Epigraphia Birmanica Duroiselle's thoughts were further refined by Blagden, ${ }^{47}$ who expressed them a bit more precisely and revealed the source of his inspiration.

The conquest of the old Môn capital of Sadhuim (in Burmese pronounced Thatôn) was a critical moment in Burmese history in the same way that the 
Roman conquest of Greece was in the history of Rome. In each case the conquered nation imparted to the conqueror many things which he lacked and which he eagerly accepted. The Burmese took over from the Môns their form of Buddhism with its Pāli canon, their particular variety of the Southern Indian alphabet, and certain useful or ornamental arts and crafts. Monks, scholars, and skilled artisans were imported in considerable numbers from the Môn country to the Burmese capital, and it is largely due to the religious, scholarly and artistic impetus thus given that Burmese civilization, as illustrated for example in the temples and inscriptions of Pagan, took its particular line and form. That is not to say that the Burmese prior to this period were a mere race of savages any more than were the Romans before they fell under the glamour of Greek art and literature. But just as Rome became in a great measure Hellenized, so the Burmese adopted much from the Môns, and a great deal of what is now supposed to be distinctively and characteristically Burmese was in fact derived by them from the Môns. . . . ${ }^{8}$

The Mon Paradigm now had a comparative western model, Greece and Rome, which the western or westernized scholarly community could appreciate even better. What was new for Burma's history-it had already been suggested for India's - was the theme of the conquered having conquered the conqueror with its culture. In addition, Duroiselle, as superintendent of the Archaeological Survey, made what turns out to have been an extremely important administrative decision: the highest priority given to the Epigraphia Birmanica went to the translation of Mon inscriptions. By the time the journal was defunct-1934, for all practical purposes-no translation of Old Burmese had yet appeared in it, except for the Burmese face of the Myazedi Inscriptions. And that was done to highlight its Mon duplicate. Thus all the scholarly and financial resources for publishing this journal went to the translation of Mon only, even though Old Burmese inscriptions outnumbered Old Mon by a ratio of nearly fifteen to one.

With such privileging of Mon sources it was virtually inevitable that the Mon Paradigm would be passed on to, and perpetuated by, other scholars of Southeast Asia who were not in positions to seriously contest the decision that made Old Mon inscriptions the first and highest priority for translation. Old Mon inscriptions became the invariable, indeed only, choice of primary data for scholars of early Southeast Asia who required this kind of firsthand source material from Burma but did not have a reading knowledge of either Old Burmese or Old Mon.

As a consequence the Mon Paradigm found its way into works that were more widely read. A good illustration of this is John Jardine's introduction to the fourth edition of Father Sangermano's old Burmese Empire. This introduction clearly revealed that whereas the Mon Paradigm had not been part 
of Jardine's preface to the second edition in 1884, by the "Introduction" to the fourth edition in 1924, it certainly was. The 1884 text was little more than three pages without a word on Mon-Burman relations. The 1924 text was over twenty-two pages that essentially reiterated Forchhammer's claims, particularly of the Mon as victim and the Burman as oppressor. It is obvious that the perception with regard to Mon-Burman history had changed significantly between the late nineteenth century (and Jardine's preface) and the third decade of the twentieth (and his introduction) of the same book.

And here, once again, western history was used to illustrate this MonBurman relationship. Only this time, Jardine had likened it to that between the Romans and the Jews. He wrote: "Conquered at last, and ill-treated by the Burmese kings, the trodden-down Talaings [my emphasis] can apply to themselves what Seneca wrote of the Jews in the Roman Empire: 'Victoribus victi leges dederunt." ${ }_{49}$

By the time the next major history of Burma written in English was published-G. E. Harvey's History of Burma in 1925-the Mon Paradigm had become gospel. It was now deeply embedded in the historiography of early Burma. It is in Harvey's work that the Aniruddha conquest story and its alleged consequences appeared in English in its fullest version for the first time..$^{50}$

Harvey concluded that the conquest brought "... the end of Thaton as a royal city, and she could not recover her prosperity by sea trade because the receding coastline left her high and dry. Anawrahta rode back in triumph to Pagan. Like some great glittering snake the victorious host uncurled its long length and set out through the Delta creeks with a captive chief and court, all the monks, and an entire population, numbering 30,000; but the pride of the Burmese was Manuha's thirty-two white elephants, each laden with scriptures and relics...."

He continued: "the influx of Thaton captives, many of them craftsmen, helped to civilise the north, and there were three immediate results. Firstly, Shin Arahan gained many helpers from the Thaton clergy, and got all the scriptures he wanted, housing them in the Tripitakataik library building which is still to be seen at Pagan. Secondly, Pali supersedes Sanskrit as the normal language of sacred books, and Hinnayāna teaching supersedes Northern Buddhism. Thirdly, the Burmese adopted the Talaing alphabet and for the first time wrote their language-the earliest inscription in Burmese is dated to 1058, the year after the conquest." ${ }_{11}$

Harvey's History was followed by the works of Luce and Pe Maung Tin, on whom many others have depended, particularly for the history of Pagán. Unlike Harvey's very human, and in many respects quite "autonomous" 
history, which relied heavily on the chronicles, Pe Maung Tin and Luce, for the most part, did not, even though Pe Maung Tin's translation of the Pagán sections of the Hmannan, published as The Glass Palace Chronicle, ${ }^{52}$ was a major contribution to that "autonomous" genre of literature. Rather, both of them based much of their work on what they considered to be original inscriptions.

Dozens of publications by Pe Maung Tin in the first two decades of the $J B R S$ hardly ever touched on the Mon Paradigm, even though, or perhaps because, he was self-conscious of his Mon cultural background. ${ }^{53}$ For Luce, however, the reverse was true. As we have seen time and again, he accepted the chronicles' account of the conquest of Thatôn as historical, and rather than attempting to disprove it, as he normally did with other accounts in the chronicles, he sought to prove it instead. ${ }^{54} \mathrm{He}$ was convinced that the Mon Paradigm was correct, as is demonstrated by virtually everything he wrote. Luce subsequently passed the mantle on to his pupils and colleagues, mainly Burmese of Mon cultural background, virtually all of whom were instrumental in the reconstruction of state and society at Pagán. To be sure, not all accepted everything he wrote, but all operated within the same analytical framework, the consolidated vision that was the Mon Paradigm.

In 1939 B. R. Pearn published A History of Rangoon. ${ }^{55}$ Basing much of his early account of Rangoon on Pe Maung Tin's translations of the Shwédagôn Pagoda Inscriptions and other local histories of religious buildings and places called thamaing, Pearn was one of the first to see through the Mon Paradigm and realize that the religious "history" of places like Rangoon and Lower Burma was actually hagiology and that its development was quite late. Although he also seemed to believe that the Mon were contemporaries with the Pyū, he ignored the thesis that the Mon had civilized Pagan, either because he was unaware of it, or, more likely, did not give it much credence. Thus he wrote, "while the rulers of Pagan had been erecting their magnificent temples, the Mons had produced nothing of comparable value, and even now in the days of their greatness their Kings had as yet aimed at no more than a stupa of sixty feet in height [a reference to the Shwédagôn Pagoda]. It is evident that the Delta had lagged far behind Upper Burma in civilisation. . . ." 56

This contrary view was simply ignored by one of the most influential scholars of Southeast Asia at the time, who also happened to be a Burma specialist: D. G. E. Hall. As he did not read Burmese, he was dependent upon Phayre, Harvey, and Luce, particularly for the indigenous, narrative side of Burma's history. Not only did he perpetuate the Mon Paradigm, but he also took it to a much larger audience located outside the country. This is what he wrote in his Burma, first published in 1950. 
... the conquest of Thaton in 1057 was a decisive event in Burmese history. It brought the Burman into direct contact with the Indian civilizing influences in the south and opened the way for intercourse with Buddhist centres overseas, especially Ceylon. The possession of the Pali scriptures revolutionized his outlook: they supplied him 'ready-made, with a complete mental outfit.' . . . They introduced him to the Buddhist ethic, which, as monasteries and teachers multiplied throughout the land, began to exert its moral force, to restrain his more barbarous impulses, and to liberate him from the worst of his animistic practices. ${ }^{57}$

In 1955 an important organization was founded that became another conduit for the Mon Paradigm: the Burma Historical Commission, which is still active today. Its publication, The Bulletin of the Burma Historical Commission, was initially produced mainly in English. At least two of the Commission's first three publications were special studies that bolstered the Mon Paradigm. These were Ba Shin's Lokahteikpan and Luce and Ba Shin's Pagán Myinkaba Kubyauk-Gyi Temple of Rajakumar, which appeared as volume 2 (1961) of the Bulletin. The third volume of the Bulletin, in 1963, was the last largely English publication, but it was never officially distributed. Only a preliminary run of a few numbers occurred before it was stopped. The Bulletin continued to be published, however, in Burmese and is still in production. ${ }^{58}$

Then in 1959 Pierre Dupont published his L'archéologie mône, which should have raised some doubts about, if not temporarily arrested the Mon Paradigm. In it, as one might recall from Chapter One, he had questioned the entire notion of an early Rāmaññadesa and suggested that the Burma Mon of the fifteenth century had "recast aspects of their past . . ." by bestowing "the dignity of age on their newly purified faith." 59 But as Dupont did not go much farther than give his interpretation of the situation, Mon Paradigm scholars did not, and were not necessarily bound to accept it. Indeed, Luce knew about and cited Dupont's work ${ }^{60}$ but did not address the issue (of an early Rāmaññadesa) raised by it. As often happened in Burma Studies in the country, the opinions of outside scholars, even if known, were sometimes simply ignored.

By the end of the first decade of the twentieth century, then, the Mon Paradigm had gained so much momentum that it had become a school of thought, and by the 1930s and 1940s it had become the only one. After World War II and into the 1950s it was no longer possible (as a practical matter) to even question it. Virtually everything that was written about early and even later Burma went towards verifying the Mon Paradigm rather than questioning it. 


\section{The Mon Paradigm in the Second Half of the Twentieth Century}

During the 1960s and into the 1970s, another Burmese detractor appeared among the few who dared, or was simply competent enough in English, to challenge the dominant western scholars on the Mon Paradigm. This was Dr. Htin Aung, president of the Burma Research Society from 1954 to 1955. Typically his challenges revolved around the hidden assumptions buried in colonial issues, which were carried out in a most enthusiastic manner. ${ }^{61}$ With regard to the Mon Paradigm, his Burmese History Before 1287 is most relevant, for his earlier History of Burma had actually accepted the conventional view. ${ }^{62}$ Some of his refutation, especially of Luce's arguments, is quite convincing. But since he seldom cited his sources or provided evidence to make his case, his work was simply a reasonable critique, not one that advanced the field in a substantive way with regard to hard data.

In contrast to Htin Aung, many more indigenous historians of Burma, including the Mon scholar Nai Pan Hla, blindly followed Luce's line of thinking. Most had formally or informally trained under Luce, and most published at least some of their works in English so that they reached a much broader and academically more influential audience than those who did not. Of these, the best known to western scholars is Dr. Than Tun.

Always the iconoclast, Than Tun was, nevertheless, very unlike Htin Aung. Whereas the latter had specialized in English literature, Than Tun was a trained historian who regularly cited his sources, and his research was ordinarily based on hard evidence, usually the original Old Burmese inscriptions. Yet he was very reluctant to criticize Luce, "his" sayagyi ("teacher"), either in public or in private. It was probably a matter of personal politeness. In his "History of Buddhism in Burma A.D. 1000-1300," originally written in 1956, Than Tun accepted the conventional version of Aniruddha's conquest of Thatôn and its consequences. ${ }^{63}$ However, his Khit Haung Myanma Yazawin [Early history of Myanma], published in Burmese in 1969, questioned the historicity of the conquest as unproved by contemporary sources. ${ }^{64}$ But he did not pursue the subject much beyond this.

In the mid-1970s Michael Mendelson's Sangha and State in Burma appeared, edited by John P. Ferguson. By then at least one aspect of the Mon Paradigm-the Theravāda Buddhist influence of Lower Burma on Upper Burma-was questioned, but no challenge was made concerning the antiquity of Mon civilization or the historicity of the conquest of Thatôn in 1057. Mendelson wrote: “. . . it is doubtful that any 'pure' form of Theravāda Buddhism existed in 1057 at Thaton [and] . . equally difficult to accept [is] the concept of a purely Theravāda Thaton, since the available data suggest 
strong Hindu and Mahayanist presences at the time it reportedly 'civilized' the Upper Burmese conquerors." ${ }^{65}$ (This thesis of a more Hindu and Brahmanic Thatôn had already been suggested as early as 1947 by Quaritch Wales. ${ }^{66}$ )

In other words, Mendelson was less concerned with the historicity of the conquest than with whether or not Thatôn (or even Ceylon at the time) had "pure" Theravāda Buddhism. The most important issue to him, as revealed in this and several other publications of his, ${ }^{67}$ was the notion of "purity" in Buddhism itself. His work did not question the Mon Paradigm per se, but he did raise doubts about issues tangentially related to it.

In 1983 Paul Wheatley, using Pierre Dupont's earlier analysis and research on Dvāravatī, also challenged the Mon Paradigm. He invoked Dupont's earlier work and directly questioned the underlying basis for the Mon Paradigm: namely, the antiquity of Rāmañnadesa. But neither he nor Dupont questioned the conquest of Thatôn itself or the civilizing of Upper Burma by Lower Burma. ${ }^{68}$

In 1985 I published Pagan: the Origins of Modern Burma. Like my predecessors, I questioned neither the antiquity of Lower Burma Mon civilization, the historicity of the conquest of Thatôn, nor the civilizing of Burman Upper Burma by a Mon Lower Burma. Part of the reason was that each new study of early Burma sought new information, approaches, and theories rather than scrutinizing older ones. There were so many areas to investigate that one ordinarily did not have to find one's niche in someone else's thesis or footnote, as often happens in more crowded areas of study. Opportunities to conduct research on something new were far greater in the study of early Burma than in many other regions of Southeast Asia, provided one had the necessary language skills. Every new early Burma scholar had the potential to become a pioneer. Thus even if the Mon Paradigm had been identified this early as questionable, it probably would not have been a high priority for anyone's research agenda in any case.

As a result of this rather large consensus favoring the Mon Paradigm, even if partly by default, other scholars of Southeast Asia who were not necessarily Burma specialists understandably also accepted the thesis. ${ }^{69}$ The Mon Paradigm had become "common knowledge" for anyone dealing with Mainland Southeast Asian history and culture.

This state of affairs continues today, so that the most recent scholarship on Burma as well as South and Southeast Asia still depends, in part, on the historicity of the Mon Paradigm. The latest PhD dissertation written on Pagán as of this writing, Tilman Frasch's work in German completed in 1996, preserves the Mon Paradigm. It endorses the alleged raid of Thatôn, its possession of the Tipitakas, and Shin Arahan's role, without questioning any of them. And for all of Frasch's proselytizing about having knowledge 
of Old Burmese being absolutely crucial to any study of Pagán, he cites Luce and The Glass Palace Chronicles as evidence for the above three "events." 70

Emmanuel Guillon also continues to perpetuate the Mon Paradigm, although he does so with some skepticism and caution regarding certain issues. ${ }^{71}$ In art history, recent works by Hiram Woodward, Claudine BautzePicron, and Donald Stadtner all acknowledge and perpetuate the Mon Paradigm although they appear to have distanced themselves, perhaps consciously, from Luce's theories. ${ }^{72}$ Most obvious in this regard is art historian John Guy, who seems to have accepted the Paradigm only reluctantly. He focuses instead on the Pyu $\bar{u}^{73}$ and gives much more credence to the idea of direct influence from India than from the Lower Burma Mon. ${ }^{74}$ Similarly, Andrew Huxley, whose work on Southeast Asian and Burma's legal history is extremely important to the field, did not question the Mon Paradigm in his earlier works. However, in a later one, he began to show some doubts, writing that ". . . if 10th century Rammanadesa was a flourishing base for legal inventiveness, it has left very few archaeological remains to testify to the fact." But later in the same article he wrote that "Mon chronicle traditions treat these centuries in a completely legendary fashion and only enter the realms of historical narration with king Manuha's defeat by Pagan in 1057, ..."75 thus suggesting that he still considers the latter event as historical.

Scholars of Buddhism, such as John Strong, understandably have also succumbed to the Mon Paradigm, particularly when writing on a subject like the Upagupta legend, which invariably included Burma. ${ }^{76}$ I should quickly add, however, that he makes clear his purpose is not to separate fact from fiction, so is quite justified in reporting what that tradition says, without necessarily endorsing its historicity. And like John Guy, Strong seems uneasy with the historical claims made by the Mon Paradigm.

I cite these excellent scholars not to disparage their works, but to show the extent to which the Mon Paradigm remains a part of current scholarship on Burma as well as South and Southeast Asia. After all, it was challenged publicly for the first time only in 2001 in a paper I presented at an annual international conference in Burma, ${ }^{77}$ and only as of this writing has it been reexamined in detail. It has taken nearly 125 years for this to happen.

\section{Conclusion}

By the early twentieth century colonial scholars had ordained as historical the three components of the Mon Paradigm: the antiquity of Rāmaññadesa, the conquest of Thatôn, and the civilizing consequences attributed to the Mon of Lower Burma. The thesis became the most important ideology in 
the historiography of early Burma. Although scholars knew that another Tibeto-Burman-speaking culture lived in and dominated Upper Burma and probably influenced Lower Burma for over a millennia, and knew that not a single contemporary source mentioned any kingdom or polity in Lower Burma prior to the late thirteenth century, that did nothing to change anyone's mind. Nor did the fact that approximately 900 inscriptions from both Upper and Lower Burma, in Burmese, Mon, and Pali failed to mention the conquest of Thatôn even once make any difference. The knowledge that not a single, dated Old Mon inscription written in the Dvāravatì Old Mon script was found in Burma, or that the Old Burmese script preceded the Old Mon script by several decades (if not more) in Burma, was cast aside as impossible. That not a trace of the true vault, the most fundamental engineering principle used at Pagán for the hollow temple, could be found at any Mon site in Southeast Asia did not seem to faze anyone. That Kyanzittha's reign was an anomaly, not a yardstick by which Pagán society and culture should have been measured, was simply inconceivable. And no one bothered to investigate whether or not the notion of the "downtrodden Talaing" had any credibility.

By the time the Mon Paradigm had become an essential part of Burma's historiography, the thesis had become larger than any single individual scholar. Too much time, energy, and material resources had gone into it, and too many personal reputations depended on its viability. Although that is not to deny that there were probably genuine convictions of its validity, those convictions were not based on original epigraphy and the kinds of sources the Mon Paradigm regularly touted as the only reliable kind; rather, they were based on the chronicles which it regularly disparaged as unreliable.

Not unlike the chroniclers, who had religious biases, colonial officials and scholars had their own concerns and prejudices that perpetuated the fiction nevertheless. One of these was that ethnicity was a tangible, concrete entity that could and did affect history, and this was particularly convincing in an age of ethnic nationalism. Another was a sentimental attachment to the idea of supporting a people thought to have been victimized by its neighbors. A third was the natural desire of scholars with an interest in antiquities to preserve what they thought was once an ancient culture that was rapidly being lost in the fast-paced modern world of the twentieth century. None of these concerns or biases are particularly impeachable, but they were, nonetheless, largely responsible for the way in which the Mon Paradigm was institutionalized. 